\title{
INFECTION PERIOD FORECASTING FOR IMPROVED APPLE BLACK SPOT MANAGEMENT IN HAWKE'S BAY
}

\author{
K.G. TATE ${ }^{1}$, R.M. BERESFORD ${ }^{2}$ P.N. WOOD ${ }^{3}$ \\ and D.W.L. MANKTELOW ${ }^{3}$ \\ ${ }^{1}$ Crop Health Services, PO Box 2153 Stortford Lodge, Hastings \\ ${ }^{2}$ HortResearch, Mt Albert Research Centre, Private Bag 92-169, Auckland \\ ${ }^{3}$ HortResearch, Hawke's Bay Research Centre, Private Bag 1401, Havelock North
}

\begin{abstract}
Two methods for timing pre-infection protective sprays for apple black spot management, infection period forecasts (IPFs) and rain probability forecasts (RPFs), were compared for their ability to predict infection periods (IPs) identified by an apple black spot infection model from September-December. For RPFs, 88\% (1993) and 81\% (1994) of recorded IPs were correctly forecast, but $58 \%$ and $81 \%$ of the forecasts falsely predicted that IPs would occur when they did not. For IPFs, $81 \%, 29 \%$ and $100 \%$ of recorded IPs were correctly forecast in 1993, 1994 and 1995 and only $28 \%, 20 \%$ and 29\% falsely predicted IPs when none occurred. IPFs were considered more useful than RPFs because of less overprediction, although the ability of IPFs to correctly predict IPs varied between years. In a field trial in 1993-94, a pre-infection protective fungicide programme, where sprays were timed using IPFs, gave as good control of black spot, with three fewer sprays, as an 'industry-standard' programme. In 1994-95, an IP-based programme which combined pre-infection spraying using IPFs, with post-infection curative fungicides after monitored IPs, gave equivalent disease control, using up to six fewer sprays, to a standard programme.
\end{abstract}

Keywords: apple black spot, infection period forecasting, fungicide spray timing

\section{INTRODUCTION}

Management of apple black spot (Venturia inaequalis Cke. Wint.) in New Zealand involves intensive cover-replacement spraying of protective fungicides with additional curative fungicides after wet weather, from green tip to early December (Beresford et al. 1989). Reduction in fungicide inputs can be achieved by focusing on curatives (demethylation inhibitor (DMI) fungicides and dodine) applied only after infection periods (IPs) are detected by weather monitoring equipment (Manktelow $e t$ al. 1989). Since 1990 during several very wet seasons, extensive curative spraying significantly increased the use of DMIs and dodine (Manktelow unpublished). This coincided with reduced sensitivity in $V$. inaequalis to DMI fungicides in New Zealand (Bakker et al. 1995). Dodine resistance was not detected but is present overseas (Sholberg et al. 1989). Since both DMIs and dodine are considered to be at-risk of selecting resistant strains of $V$. inaequalis their use should be minimised. This could be achieved by increasing the efficiency of protective spraying by using weather forecasts to time applications to just before IPs.

Forecasts of wetness and temperature conditions favouring V. inaequalis ascospore infections were tested in New Zealand during 1987-88, but were replaced in 1989 by rain probability forecasts (RPFs) when their accuracy was found to be too low. RPFs arose from the reliability of fine weather forecasts and were intended for delaying protective sprays during fine periods in black spot management, thereby reducing fungicide use (Beresford and Spink 1992). Their value for fungicide management has not been documented. 
From 1990-96, infection period forecasts (IPFs) based on prognostic weathersituation maps (Tate 1993) were tested in Hawke's Bay (Tate et al. 1995). These reopened the possibility of accurate pre-infection spray timing with reduced need for curative sprays. This paper compares RPFs and IPFs and evaluates their usefulness for preinfection spraying in two field trials.

\section{METHODS}

Daily IPFs (Tate 1993) were compared with daily RPFs (MetService, Wellington, as described by Beresford and Spink 1992) during 1993-95. RPFs were interpreted to predict IPs when rainfall probability was stated as 'reasonably certain' or 'certain'. The accuracy and usefulness of each type of forecast was assessed by comparing them with IPs identified by the Orchard 2000 black spot model 'Spot Check' (Laurenson et al. 1994), which uses infection criteria described by MacHardy and Gadoury (1989), from 1 September to 31 December each year. Weather data were from an electronic weather station at Twyford in Hawke's Bay.

To test the effectiveness of IPFs for black spot spray timing, pre- and postinfection spray programmes were compared in spring 1993 at the HortResearch Lawn Road research apple orchard in Hawke's Bay. Rainy periods comprising several successive IPs were treated as single IPs if total rainfall was less than about $15 \mathrm{~mm}$. Three replicates each of Braeburn and Royal Gala were used in a randomised-block trial with three-tree plots. An 'industry-standard' programme (protective sprays timed by growth stage and calendar, with curative sprays after prolonged wet weather) and an unsprayed control were also included. In 1994-95 an IP-based programme combining pre-infection protective with post-infection curative spraying (for unpredicted IPs or long, rainy periods), was compared with standard spraying. Large blocks (4-6 rows) of Gala, Royal Gala, Braeburn and Fuji (total of five replicates) at Lawn Road were used.

Sprays in 1993-94 were applied to the point of run-off by hand-operated knapsack sprayer and in 1994-95 by airblast sprayer at 1000-2000 litres water/ha. Post-infection sprays were timed with the Spot Check monitor, using weather data from the same orchard, and standard spray timing was decided by the orchard manager. In 1993-94 the centre tree of each plot was assessed for disease, while in 1994-95, eight widely separated trees in the centre row of each block were assessed. Percent black spot incidence was visually assessed on leaves and/or fruit in December and at harvest on 10 randomly selected shoots and 100 fruit per tree (Beresford and Manktelow 1995).

\section{RESULTS AND DISCUSSION \\ Relative IP forecasting accuracy by both systems}

In $1993,88 \%$ of recorded IPs were predicted by RPFs but 58\% (19) of RPFs predicted IPs when they did not occur (false positives or overprediction) (Table 1). By comparison, IPFs predicted $81 \%$ of the recorded IPs and only $28 \%$ (3) were false positives. In 1994, $86 \%$ of recorded IPs were predicted by RPFs but $81 \%$ (50) were false-positives, while IPFs predicted only $29 \%$ of IPs with $20 \%$ (1) a false-positive. In 1995 (RPFs not evaluated), IPFs predicted 100\% of recorded IPs and 29\% (5) were false positives.

Although RPFs predicted $86-88 \%$ of recorded IPs over two seasons, their usefulness for pre-infection spray timing was negated by the large numbers (19-50) of false positives. IPFs made more consistently-correct predictions of whether or not an IP would occur (71-80\% over 3 years) and had a relatively low incidence of false positives (20-29\%).

In 1994, IPFs predicted only $29 \%$ of recorded IPs, i.e. $71 \%$ false negatives. For diseases where eradication of new infections is not possible this would negate the usefulness of IPFs in spray timing. However for apple black spot, false negative IPFs can be effectively redressed by curative sprays. In IP-based spraying the number of curative sprays required each season would depend on the incidence of false negative IPFs which varies with the weather conditions and prognostic information available. While a high percentage ( $71 \%$ ) of false negative IPFs occurred in 1994, over the 3 years this averaged 
out to $26 \%$, enabling a reduction in use of at-risk curative sprays over the longer term. The risk remains in both cover-replacement and IP-based spraying that poor timing or false negative IPFs respectively, will result in inadequate protection at the start of a long wet period, which exceeds the reachback ability of curative sprays.

For both types of forecast about 2 days lead time was available to apply sprays before the predicted rain events. The number of positive forecasts made too late to respond with pre-emptive spraying averaged about 0.5 per season for each system.

TABLE 1: Accuracy of rain probability forecasts (RPFs) and infection period forecasts (IPFs) in predicting apple black spot infection periods (IPs) monitored at Twyford, Hawke's Bay, during SeptemberDecember, 1993 to 1995.

\begin{tabular}{lccccc}
\hline & \multicolumn{2}{c}{1993} & \multicolumn{2}{c}{1994} & 1995 \\
Category & RPFs & IPFs & RPFs & IPFs & IPFs \\
\hline No. of IPs recorded & 16 & 16 & 14 & 14 & 12 \\
No. of IPs forecast & 33 & 18 & 62 & 5 & 17 \\
No. of correct IPFs & 14 & 13 & 12 & 4 & 12 \\
(\% of correct IPFs) & $(42)$ & $(72)$ & $(19)$ & $(80)$ & $(71)$ \\
(\% of recorded IPs correctly forecast) & $(88)$ & $(81)$ & $(86)$ & $(29)$ & $(100)$ \\
No. of false positive IPFs (IP did not occur) & 19 & 3 & 50 & 1 & 5 \\
(\% of false positive IPFs) & $(58)$ & $(28)$ & $(81)$ & $(20)$ & $(29)$ \\
No. of false negative IPFs (IP did occur) & 1 & 2 & 2 & 10 & 0 \\
(\% of false negative IPFs) & $(7)$ & $(13)$ & $(14)$ & $(71)$ & $(0)$ \\
Mean lead time for spraying (days) & 1.9 & 1.8 & 2.5 & 1.4 & 1.2 \\
\hline
\end{tabular}

\section{Use of IPFs in spray timing trials - 1993-94}

The first dodine spray on 11 September was growth stage-based. From 19 September to end of December, 17 IPs were identified by the Spot Check monitor and substantial black spot developed in unsprayed trees (Table 2). During this period, nine sprays were applied in both pre- and post-infection spray programmes for Braeburn and eight for Royal Gala, while 12 sprays (Braeburn) and 11 (Royal Gala) were applied in the standard programme. After December a further 3-4 sprays were applied to the three spray programmes at identical timings. The pre-infection spray on 8 October followed a false-positive forecast and probably did not influence black spot control. On 21 November a curative fenarimol (DMI) spray was applied across all sprayed programmes following an unpredicted IP.

The 8 or 9 spray pre-infection programme gave equivalent black spot control to the 11 or 12 spray standard programme. Pre-infection sprays were no more than six days (average 2.7) in advance of IPs. Seven days was considered the effective life of a protective fungicide deposit on susceptible tissues.

The higher incidence of fruit disease in the post-infection programme than in the other spray programmes (Table 2 ) was probably due to inadequate protection provided by the fenarimol spray on 2 November, for the IP of 6 November (exceeded 2-3 day reachback ability).

The trial demonstrated that pre-infection spraying using IPFs can, with fewer sprays, give disease control equivalent to the standard approach based on calendar and growth stages. This suggests that reliance on DMI fungicides applied after IPs may not be necessary for effective black spot control.

1994-95

In 1994, 10 IPs were recorded from September-December (Table 3). The spray programme comparison did not start until after the first Braeburn spray. Thereafter, six sprays were applied in the IP-based programme with four being curative sprays following false-negative IPFs (unpredicted IPs) and one an unnecessary spray following a false-positive IPF. By comparison, nine sprays were applied in the 
standard programme to Braeburn and eight to the other varieties. Eight of these were protective sprays and one a curative. After December a further 3-5 sprays were applied in the standard programme (total 13-15) and 1-2 in the IP-based programme (total 89). Disease levels were low throughout the trial and there were no significant treatment differences. The IP-based programme had 5-6 fewer sprays until harvest than the standard programme with no more disease. Although very little disease developed in the 1994-95 trial, it can be said that black spot control in the IP-based programme, with significantly fewer sprays, was no worse than in the standard programme. However, three more curatives were required in the IP-based than in the standard programme.

TABLE 2: Timing of three spray programmes during the 1993 ascospore release season in relation to infection period (IP) dates and rainfall, and resulting black spot incidence (means over Braeburn and Royal Gala apple cultivars).

\begin{tabular}{|c|c|c|c|c|c|c|c|c|}
\hline \multirow[b]{2}{*}{$\begin{array}{l}\text { Monitored } \\
\text { IP start } \\
\text { date/risk }\end{array}$} & \multirow[b]{2}{*}{$\begin{array}{c}\text { Rainfall } \\
(\mathrm{mm})\end{array}$} & \multicolumn{3}{|c|}{ Pre-infection } & \multicolumn{2}{|c|}{ Post-infection } & \multirow{2}{*}{$\begin{array}{l}\text { Standard } \\
\text { Spray } \\
\text { dates/ } \\
\text { fungds }\end{array}$} & \multirow{2}{*}{$\begin{array}{l}\text { Unspr. } \\
\text { control }\end{array}$} \\
\hline & & \multicolumn{2}{|c|}{$\begin{array}{l}\text { Spray } \\
\text { dates/ } \\
\text { fungds }\end{array}$} & $\begin{array}{l}\text { Days to } \\
\text { start of } \\
\text { next IP }\end{array}$ & $\begin{array}{l}\text { Spray } \\
\text { dates/ } \\
\text { fungds }\end{array}$ & $\begin{array}{l}\text { Days to } \\
\text { start of } \\
\text { IP }\end{array}$ & & \\
\hline 19.9/Ma & 0.4 & \multicolumn{2}{|c|}{$11.9 \mathrm{~d}^{1}$} & 8 & $20.9^{2}$ & -1 & $11.9 \mathrm{~d}^{3}$ & - \\
\hline 20.9/L & 7.0 & \multicolumn{2}{|c|}{-} & & - & & - & - \\
\hline 26.9/Ma & 1.9 & \multicolumn{2}{|c|}{$22.9 \mathrm{~d}$} & 4 & 29.9 & -3 & $22.9 \mathrm{~d}$ & - \\
\hline - & 0.0 & \multicolumn{2}{|c|}{$8.10 \mathrm{~d}$} & -3 & 12.10 & & $08.10 \mathrm{~d}$ & - \\
\hline $01.11 / \mathrm{L}$ & 14.8 & \multicolumn{2}{|c|}{$31.10 \mathrm{~m}$} & $1^{4}$ & 02.11 & -1 & $18.10 \mathrm{~m}$ & - \\
\hline $03.11 / \mathrm{Ma}$ & 0.6 & \multicolumn{2}{|c|}{-} & & - & & $31.10 \mathrm{~m}$ & - \\
\hline $06.11 / \mathrm{M}$ & 12.4 & \multicolumn{2}{|l|}{-} & 6 & - & & $02.11 \mathrm{mf}$ & - \\
\hline $12.11 / \mathrm{L}$ & 6.2 & \multicolumn{2}{|c|}{$10.11 \mathrm{~m}$} & 2 & 15.11 & -3 & $10.11 \mathrm{~m}$ & - \\
\hline $16.11 / \mathrm{L}$ & 0.5 & \multicolumn{2}{|c|}{-} & & - & & $15.11 \mathrm{mf}$ & - \\
\hline $21.11 \mathrm{M}$ & 3.2 & \multicolumn{2}{|c|}{ 23/11f } & na & 23.11 & -2 & $23.11 \mathrm{mf}$ & - \\
\hline 24-5.11/M & 7.6 & \multicolumn{2}{|c|}{-} & & - & & - & - \\
\hline $03.12 / \mathrm{Ma}$ & 3.3 & \multicolumn{2}{|c|}{$02.12 \mathrm{c}$} & 1 & 07.12 & -4 & $07.12 \mathrm{mf}$ & - \\
\hline $06.12 / \mathrm{Ma}$ & 4.5 & \multicolumn{2}{|c|}{-} & & - & -1 & - & - \\
\hline $08.12 / \mathrm{Ma}$ & 1.9 & \multicolumn{2}{|l|}{ - } & & - & & - & - \\
\hline $17.12 / \mathrm{L}$ & 8.1 & \multicolumn{2}{|c|}{$15.12 \mathrm{c}$} & 2 & 21.12 & -4 & $21.12 \mathrm{f}$ & - \\
\hline $19.12 / \mathrm{L}$ & 1.5 & \multicolumn{2}{|l|}{-} & & - & & - & - \\
\hline $22.12 / \mathrm{L}$ & 2.3 & \multicolumn{2}{|l|}{-} & & - & & - & - \\
\hline $26.12 / \mathrm{Ma}$ & 5.2 & \multicolumn{2}{|c|}{$23.12 \mathrm{c}$} & 3 & 28.12 & -2 & $28.12 f$ & \\
\hline \multicolumn{9}{|c|}{$5 \%$ black spot (31.12) } \\
\hline & \multicolumn{2}{|c|}{ Terminal leaves } & \multicolumn{2}{|c|}{$0.5 \mathrm{a}$} & \multicolumn{2}{|c|}{$1.1 \mathrm{a}$} & $0.4 \mathrm{a}$ & $9.8 \mathrm{~b}$ \\
\hline & \multicolumn{2}{|c|}{ Cluster leaves } & \multicolumn{2}{|c|}{$3.3 \mathrm{a}$} & \multicolumn{2}{|c|}{$8.0 \mathrm{a}$} & $0.1 \mathrm{a}$ & $21.9 \mathrm{~b}$ \\
\hline $5 \%$ black sp & t & & & & & & & \\
\hline & $(31.12) \quad \mathrm{fl}$ & uit & 0.1 & & & $2 b$ & $0.0 \mathrm{a}$ & $22.1 \mathrm{c}$ \\
\hline & Harvest $\mathrm{fr}$ & uit & 0.3 & & & $2 \mathrm{~b}$ & $0.0 \mathrm{a}$ & $54.0 \mathrm{c}$ \\
\hline
\end{tabular}

${ }^{1}$ Braeburn only (growth stage-based spray). Flowering started on 1.10.93 (Braeburn) or 7.10.93 (Royal Gala). $\mathrm{d}=$ dodine (Syllit SC, 80ml/1001), $\mathrm{m}=$ metiram (Polyram DF, 125g/1001), $\mathrm{c}=$ captan (Orthocide, 125g/1001), $\mathrm{f}=$ fenarimol (Rubigan SC, 25ml/ 1001). IP risk: $\mathrm{Ma}=$ marginal, $\mathrm{L}=$ light, $\mathrm{M}=$ moderate, $\mathrm{S}=$ severe.

${ }^{2}$ fenarimol (4 days curative reachback and 3-4 days protective ability) was used exclusively.

${ }^{3}$ false positive IP forecast. na = not applicable (curative spray following false negative IP forecast).

${ }^{4}$ for spray timing, clustered IPs during rainy periods were treated as single IPs until $15 \mathrm{~mm}$ rain had fallen.

${ }^{5}$ means within rows followed by the same letter do not differ significantly $(\mathrm{P}<0.05)$. 
TABLE 3: Effect of infection period (IP)-based and standard spray programmes during the 1994 ascospore discharge season, in relation to IP dates and rainfall, and resulting black spot incidence (means over Braeburn, Fuji, Gala and Royal Gala apple cultivars).

\begin{tabular}{|c|c|c|c|}
\hline \multirow{2}{*}{$\begin{array}{l}\text { Monitored IP } \\
\text { start date/risk }\end{array}$} & \multirow{2}{*}{$\begin{array}{l}\text { Rainfall } \\
(\mathrm{mm})\end{array}$} & \multicolumn{2}{|c|}{ Spray dates \& fungicides applied } \\
\hline & & IP-based & Standard \\
\hline $14.9 / \mathrm{L}^{1}$ & 2.1 & $16.9 c^{2}$ & $16.9 c^{2}$ \\
\hline- & - & $22.9 c^{2}$ & $22.9 d$ \\
\hline $2.10 / \mathrm{Ma}$ & 4.5 & $28.9 \mathrm{c}$ & $30.9 d$ \\
\hline $4.10 / \mathrm{Ma}$ & 1.3 & $5.10 \mathrm{~d}$ & - \\
\hline $14.10 / \mathrm{Ma}$ & 14.5 & $17.10 \mathrm{fm}$ & $10.10 \mathrm{~d}$ \\
\hline $25.10 / \mathrm{Ma}$ & 0.3 & $28.10 \mathrm{fm}$ & $19.10 \mathrm{~m}$ \\
\hline $31.10 / \mathrm{S}$ & 11.0 & - & $28.10 \mathrm{fm}$ \\
\hline 7.11/Ma & 3.6 & $11.11 \mathrm{my} / \mathrm{t}$ & $11.11 \mathrm{~d}$ \\
\hline $29.11 / \mathrm{M}$ & 2.8 & - & $25.11 \mathrm{c}$ \\
\hline $30.11 / \mathrm{Ma}$ & 1.8 & - & - \\
\hline $10.12 / \mathrm{L}$ & 0.3 & - & $1.12 c^{2}$ \\
\hline- & - & - & $23.12 \mathrm{c}$ \\
\hline \multirow[t]{4}{*}{$4 \%$ Black spot on: } & leaves (6.12) & 0.02 & 0.05 \\
\hline & fruit $(6.12)$ & 0.05 & 0.03 \\
\hline & leaves $(15.2 .95)$ & 0.02 & 0.02 \\
\hline & fruit $(15.2 .95)$ & 0.00 & 0.09 \\
\hline
\end{tabular}

${ }^{1}$ infection risk: $\mathrm{Ma}=$ marginal, $\mathrm{L}=$ light, $\mathrm{Mo}=$ moderate, $\mathrm{S}=$ severe.

${ }^{2}$ Braeburn only. $\mathrm{c}=$ captan, $\mathrm{d}=$ dodine, $\mathrm{t}=$ thiram (Thiram $\left.80 \mathrm{~W}, 150 \mathrm{~g} / 1001\right), \mathrm{m}=$ metiram, $\mathrm{f}=$ flusilazole, $\mathrm{my}=$ myclobutanil (Systhane 40W, $11 \mathrm{~g} / 1001$ ). Rates for others as in Table 2.

${ }^{3}$ false positive IP forecast.

${ }^{4}$ means of 4 varieties, no significant treatment differences.

\section{CONCLUSIONS}

In earlier studies of the use of weather forecasts to predict black spot IPs for preinfection spraying (Beresford et al. 1989; Beresford and Spink 1992), only dry weather forecasts were accurate enough for spray timing (enabling a delay in the next scheduled protective spray). The present study shows that with RPFs, while one can delay the next fungicide spray when fine weather is forecast, the risk of applying the next spray prematurely remains high due to the large number of positive rain forecasts that are likely before the next IP occurs.

IPFs focus only on weather systems likely to produce IPs. This allows the exclusion of many weather systems which contain rain but which might lead to false positive forecasts. The system has been tested in Hawke's Bay and Gisborne for a range of wet weather fruit diseases and has allowed successful pre-infection spraying in both regions. The use of IPFs is the most efficient way to time protective fungicides and has the potential to assist in fungicide resistance management for at-risk fungicides by restricting their use to high-risk growth stages or when they are required, after either unpredicted IPs or prolonged wet periods when breakdown of previous fungicide protection is suspected.

\section{ACKNOWLEDGEMENTS}

Technical assistance by Isabelle Sorenson and Stewart Agnew is acknowledged. Jack Hughes provided the standard spray programme. This work was funded by MAFPolicy and the Foundation for Research, Science and Technology. 


\section{REFERENCES}

Bakker, G.R., Butcher, M.R. and Gaunt, R.E., 1995. Sensitivity of apple black spot to fenarimol. flusilazol, myclobutanil, penconazole and dodine in New Zealand. Proc. 48th N.Z. Plant Prot. Conf: 7-11.

Beresford, R.M. and Manktelow, D.W., 1995. Methods for disease assessment in apples, including growth stages, leaf emergence, black spot and powdery mildew. Proc. 48th N.Z. Plant Prot. Conf: 89-94.

Beresford, R.M., Salinger, M.J., Bruce, P.E. and Brook, P.J., 1989. Frequency of infection periods for Venturia inaequalis in New Zealand and implications for fungicide use. Proc. 42nd N.Z. Weed and Pest Control Conf: 159-164.

Beresford, R.M. and Spink, M., 1992. A national disease forecasting system for apple blackspot (Venturia inaequalis) in New Zealand. Acta Horticulturae 313: 285296.

Laurenson, M.R., Buwalda, J.G. and Walker, J.T.S., 1994. Orchard 2000 - a decision support system for New Zealand's orchard industries. N.Z. J. Crop and Hort. Sci 22: 239-250.

MacHardy W.E. and Gadoury D.M., 1989. A revision of Mills' criteria for predicting apple scab infection periods. Phytopath. 79: 304-310.

Manktelow, D.W., Beresford, R.M., Salinger, M.J., Bruce, P.E. and Gaunt, R.E., 1989. Use of forecast and monitored weather information for timing apple black spot fungicide applications in Canterbury.Proc. $42 n d$ N.Z. Weed and Pest Control Conf: 165-169.

Sholberg, P.L., Yorston, J.M. and Warnock, D., 1989. Resistance of Venturia inaequalis to benomyl and dodine in British Columbia, Canada. Plant Dis. 73: 667-669.

Tate, K.G., 1993. Infection period prediction for improved orchard disease management in Hawke's Bay. Proc. Annual Convention 1993, N.Z. Soc. Hort. Sci. p 33 (abstr.).

Tate, K.G., Wood, P.N. and Manktelow, D.W., 1995. Development of an improved spray timing system for process peach in Hawke's Bay. Proc. 48th N.Z. Plant Prot. Conf: 101-106. 